Article

\title{
Efficient Tissue Culture Protocol for Magnolia lucida (Magnoliaceae) and Confirmation of Genetic Stability of the Regenerated Plants
}

\author{
Lu Kang ${ }^{1,2,+} \mathbb{0}$, Keyuan Zheng ${ }^{3,+}$, Yuqing Xie ${ }^{1,2}$, Yanwen Deng ${ }^{1,2} \oplus$, Yina Yu ${ }^{1,2}$, Mulan Zhu ${ }^{3}$, \\ Ruchun $\mathrm{Xi}^{1,2, *}$ and Xiaomei Deng ${ }^{1,2, *}$ \\ 1 Guangdong Key Laboratory for Innovative Development and Utilization of Forest Plant Germplasm, \\ Guangzhou 510642, China; gnaklu@163.com (L.K.); serumia@163.com (Y.X.); hinmentang@gmail.com (Y.D.); \\ gzyyn@163.com (Y.Y.) \\ 2 College of Forestry and Landscape Architecture, South China Agricultural University, \\ Guangzhou 510642, China \\ 3 Shanghai Chenshan Plant Science Research Center, Chinese Academy of Sciences, Shanghai 201602, China; \\ 13086036031@163.com (K.Z.); mlzhu@cemps.ac.cn (M.Z.) \\ * Correspondence: xirc2006@scau.edu.cn (R.X.); dxmei2006@scau.edu.cn (X.D.); \\ Tel.: +86-137-1115-0636 (R.X.); +86-137-1116-8219 (X.D.) \\ + These authors equally contributed to this work.
}

Received: 17 June 2020; Accepted: 3 August 2020; Published: 5 August 2020

check for updates

\begin{abstract}
Magnolia lucida (Magnoliaceae) is classified as an endangered species by the International Union for Conservation of Nature. It has high commercial value owing to its attractive tree shape and flowers. We adopted an excellent genotype of M. lucida as the parent material and established a mini-cut orchard through grafting to provide trunk shoots explants over the long-term. Optimal sterilization was achieved using a combination of $75 \%$ ethanol for $30 \mathrm{~s}$, one percent benzalkonium bromide for five minutes, and $0.1 \%$ mercuric chloride for five minutes. Modified Murashige and Skoog medium (ML) was the optimal medium for the growth of M. lucida. Addition of one mg/L of 6-benzyl adenine (BA) and $0.05 \mathrm{mg} / \mathrm{L}$ of $\alpha$-naphthaleneacetic acid (NAA) to the medium increased the shoot induction rate to $95.56 \%$, and the ML medium containing $0.4 \mathrm{mg} / \mathrm{L} \mathrm{BA}$ and $0.04 \mathrm{mg} / \mathrm{L} \mathrm{NAA}$ achieved the maximum multiplication rate $(284.56 \%)$. Dark treatment for seven days, followed by continuous light treatment could better resolve the challenge of difficult rooting in M. lucida plants. Using random amplified polymorphic DNA and inter simple sequence repeat markers, we confirmed the genetic uniformity and stability of the regenerated plants. Our protocol should be helpful for the propagation and conservation of this endangered plant.
\end{abstract}

Keywords: sterilization; shoot initiation; shoot proliferation; rooting; genetic fidelity assessment

\section{Introduction}

Magnolia lucida (B. L. Chen \& S. C. Yang) V. S. Kumar, which belongs to Magnoliaceae, is a popular ornamental tree that can be used for landscaping [1]. The tepals of M. lucida are obovate-oblong, with purplish-red middle and upper parts, and a white base. The leaves of this excellent genotype are highly ornamental; the tender leaves are ochre brown and mature leaves are dark green (Figure 1a,b) [2]. Additionally, M. lucida, with a straight trunk and an excellent material structure, is a valued timber species in Southeast Yunnan, China [1,3]. However, owing to the destruction of its habitat, overdevelopment, and low natural regeneration [4,5], M. lucida is classified as an endangered species by the International Union for Conservation of Nature [6]. Thus, there is an urgent need to protect and utilize M. lucida using effective methods. 

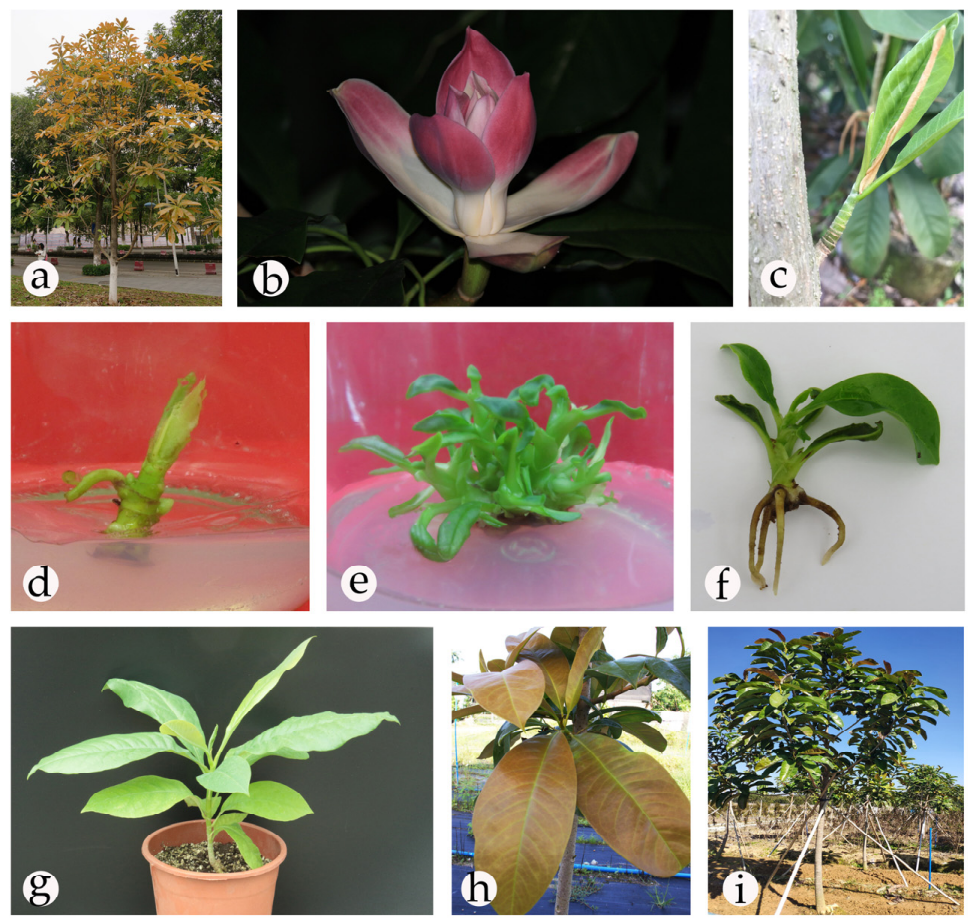

Figure 1. Micropropagation of Magnolia lucida using trunk shoot explants; (a) mother plant (excellent genotype); (b) flower; (c) trunk shoot explant; (d) shoot initiation for 20 days; (e) multiple shoot regeneration for 20 days; (f) root of regenerated plantlets; (g) the plantlets after acclimatization for 90 days; (h) regenerated plantlets with ochre brown tender leaves; (i) regenerated plantlets in the field.

Currently, the propagation of M. lucida is usually done by generating seedlings and grafting. However, the progeny propagated by seed have wide variation, and the excellent characteristics of the mother plant cannot be preserved well in them $[7,8]$. In addition, the occurrence of a partial crown is common in grafting and cutting propagation, which reduces the ornamental value. Moreover, propagation by grafting cannot produce enough progeny because the cuttings of the mother plant are limited. With its effectiveness, plant tissue culture has made significant contributions to the addressing of reproduction-related challenges in Magnoliaceae [9]. Several precious Magnolia species, such as M. punduana, M. sirindhorniae, and M. dealbata, have been successfully propagated using tissue culture [10-12]. However, owing to the high levels of phenols in magnolias, it is challenging to establish an aseptic system; additionally, it is difficult to induce rooting in the regenerated plants [9]. Thus, the in vitro propagation of most endangered Magnoliaceae such as M. lucida has not been accomplished [3]. The difficulty in the in vitro propagation of $M$. lucida is due to the limited explant availability because the twigs of a mature tree or withes at the base of the trunk are very thick and thus not conducive to explant sterilization and shoot induction. Therefore, the selection of a suitable explant is paramount for the successful micropropagation of M. lucida.

Several factors, such as medium composition and growth conditions, may cause considerable variations in the regenerated plants in the process of tissue culture [13,14]. Therefore, the evaluation of genetic uniformity of regenerated plants is particularly important. Random amplified polymorphic DNA (RAPD) and inter simple sequence repeat (ISSR) markers are extensively used to assess genetic fidelity, and they have been successfully used in many plants, such as Vinca minor, Foeniculum vulgare, and Pisum sativum [15-17].

The objective of this study was to establish a reliable method for conserving and reproducing M. lucida excellent genotypes by tissue regeneration, and to analyze the genetic stability of regenerated plants. 


\section{Results}

\subsection{Establishment of an Aseptic System}

In this study, sterilization effects of three chemical disinfectants for M. lucida explants were compared alone or in combination (Table 1). Among the seven treatments, the best result was achieved with the $75 \%$ ethanol $\left(\mathrm{C}_{2} \mathrm{H}_{6} \mathrm{O}\right)$ for $30 \mathrm{~s}, 1 \%$ benzalkonium bromide $\left(\mathrm{C}_{21} \mathrm{H}_{38} \mathrm{BrN}\right)$ for 5 min, and $0.1 \%$ mercuric chloride $\left(\mathrm{HgCl}_{2}\right)$ for 5 min combination. With this combination, the survival rate of explants increased up to $78 \%$. The lowest survival rate was observed with benzalkonium bromide alone, followed by ethanol. The survival rate of explants increased, and then decreased with the extension of mercuric chloride disinfection; when $0.1 \%$ mercuric chloride was used for $7 \mathrm{~min}$, the survival rate was reduced and the explants showed a rotted appearance. Other treatments generally induced a moderate response in the explants.

Table 1. Effectiveness of different sterilization schemes.

\begin{tabular}{ccccc}
\hline \multirow{2}{*}{ No. } & \multicolumn{4}{c}{ Treatment Composition (Duration) } \\
\cline { 2 - 5 } & Ethanol 75\% (s) & Benzalkonium Bromide 1\% (min) & Mercuric Chloride 0.1\% (min) & Survival (\%) \\
\hline 1 & - & 5 & - & 4 \\
2 & - & - & 5 & 27 \\
3 & 30 & - & 1 & 56 \\
4 & 30 & 5 & 3 & 68 \\
5 & 30 & 5 & 5 & 78 \\
6 & 30 & 5 & 7 & 61 \\
\hline
\end{tabular}

\subsection{Shoot Initiation}

The explants were induced on four media to select the optimal one (Table 2). Among the four media, ML (a modified MS medium) was the optimal medium for shoot induction, followed by Douglas-fir cotyledon revised (DCR) medium [18]. Although shoot induction and growth were observed on Murashige and Skoog (MS) medium [19] and woody plant medium (WPM) [20], the shoots that appeared were unhealthy. Furthermore, the shoots had a low induction rate and grew slowly, and then stopped growing or died in the last stage. The shoot showed faster elongation on ML medium, appearing verdant green and robust (Figure 1d). In addition, we found that the induction effect of $\alpha$-naphthaleneacetic acid (NAA) was superior to that of indole-3-butyric acid (IBA) at the similar concentrations. Based on the rate of induction and growth, the optimal medium for the initial induction was ML + 6-benzyladenine (BA) $(1 \mathrm{mg} / \mathrm{L})+\mathrm{NAA}(0.05 \mathrm{mg} / \mathrm{L})$.

Table 2. Effects of different media on the initial shoot induction.

\begin{tabular}{|c|c|c|c|c|c|c|}
\hline No. & Medium & BA $(\mathrm{mg} / \mathrm{L})$ & NAA (mg/L) & IBA $(\mathrm{mg} / \mathrm{L})$ & Induction Rate (\%) (Mean $\pm \mathrm{SE} ; n=3)$ & Observation \\
\hline 1 & ML & 1 & 0.05 & - & $95.56 \pm 3.14^{\mathrm{a}}$ & Robust and green shoots \\
\hline 2 & ML & 1 & - & 0.05 & $85.56 \pm 1.57^{\mathrm{b}}$ & Robust and green shoots \\
\hline 3 & ML & 1 & - & - & $60.00 \pm 2.72 \mathrm{de}$ & Slow growth of shoots \\
\hline 4 & DCR & 1 & 0.05 & - & $74.44 \pm 4.16^{c}$ & Green shoots \\
\hline 5 & DCR & 1 & - & 0.05 & $63.33 \pm 2.72^{d}$ & Slow growth of shoots \\
\hline 6 & DCR & 1 & - & - & $48.89 \pm 3.14$ ghi & Slow growth of shoots \\
\hline 7 & WPM & 1 & 0.05 & - & $57.78 \pm 4.16^{\mathrm{def}}$ & Slow growth of shoots \\
\hline 8 & WPM & 1 & - & 0.05 & $51.11 \pm 5.67^{\mathrm{fgh}}$ & Slow growth of shoots \\
\hline 9 & WPM & 1 & - & - & $42.22 \pm 1.57^{\mathrm{i}}$ & Slow growth of shoots \\
\hline 10 & MS & 1 & 0.05 & - & $53.33 \pm 5.44$ efg & Hyperhydricity \\
\hline 11 & MS & 1 & - & 0.05 & $43.33 \pm 4.71 \mathrm{hi}$ & Hyperhydricity \\
\hline 12 & MS & 1 & - & - & $33.33 \pm 5.44^{j}$ & Hyperhydricity, browning \\
\hline
\end{tabular}

Different superscript letters in the same column indicate significant differences at $p \leq 0.05$. $n=3$ indicates three replicates. BA: 6-benzyladenine; NAA: $\alpha$-naphthaleneacetic acid; IBA: indole-3-butyric acid; ML: modified MS medium; DCR: Douglas-fir cotyledon revised medium; WPM: Woody plant medium; MS: Murashige and Skoog medium. 


\subsection{Shoot Proliferation}

In the subsequent experiments, 16 combinations of BA and NAA concentrations were compared to optimize growth (Table 3). The optimal BA concentration was $0.4 \mathrm{mg} / \mathrm{L}$ and the optimal NAA concentration was $0.04 \mathrm{mg} / \mathrm{L}$. Among the various combinations tested, the highest number (5.3) of shoots per explant was obtained on ML medium containing $0.6 \mathrm{mg} / \mathrm{L} \mathrm{BA}$ and $0.04 \mathrm{mg} / \mathrm{L} \mathrm{NAA}$. The maximum shoot multiplication rate (284.56\%) was obtained on ML medium containing $0.4 \mathrm{mg} / \mathrm{L} \mathrm{BA}$ and $0.04 \mathrm{mg} / \mathrm{L} \mathrm{NAA}$, on which the shoot clusters were verdant green and thriving, without defoliation or hyperhydricity (Figure 1e).

Table 3. Effects of different combinations of BA and NAA concentrations on shoots proliferation.

\begin{tabular}{|c|c|c|c|c|c|}
\hline No. & BA $(\mathrm{mg} / \mathrm{L})$ & NAA (mg/L) & $\begin{array}{l}\text { Multiplication Rate (\%) } \\
\quad(\text { Mean } \pm \text { SE, } n=3)\end{array}$ & $\begin{array}{c}\text { Number of Shoots per Explant }(\geq 0.5 \mathrm{~cm}) \\
(\text { Mean } \pm \text { SE, } n=3)\end{array}$ & Growth State of Buds \\
\hline 1 & 0 & 0 & $98.87 \pm 4.93^{1}$ & $1.20 \pm 0.08^{\mathrm{h}}$ & Shorter shoots \\
\hline 2 & 0.2 & 0.02 & $247.85 \pm 5.65$ ef & $4.07 \pm 0.21^{\mathrm{d}}$ & Shorter shoots \\
\hline 3 & 0.2 & 0.04 & $253.54 \pm 3.27$ de & $4.60 \pm 0.14^{b}$ & Shorter shoots \\
\hline 4 & 0.2 & 0.06 & $235.91 \pm 3.18^{g}$ & $3.63 \pm 0.12^{\mathrm{e}}$ & Shorter shoots \\
\hline 5 & 0.2 & 0.08 & $215.90 \pm 6.27^{\mathrm{hi}}$ & $3.00 \pm 0.08^{\mathrm{f}}$ & Partial callus \\
\hline 6 & 0.4 & 0.02 & $274.69 \pm 3.15^{b}$ & $4.70 \pm 0.08^{b}$ & Robust shoots \\
\hline 7 & 0.4 & 0.04 & $284.56 \pm 3.88^{\mathrm{a}}$ & $5.17 \pm 0.12^{\mathrm{a}}$ & Robust shoots \\
\hline 8 & 0.4 & 0.06 & $267.85 \pm 5.82 \mathrm{bc}$ & $4.50 \pm 0.22^{b}$ & Robust shoots \\
\hline 9 & 0.4 & 0.08 & $250.69 \pm 4.52$ def & $4.43 \pm 0.21 \mathrm{bc}$ & Partial shoots \\
\hline 10 & 0.6 & 0.02 & $259.58 \pm 8.67^{c d}$ & $4.37 \pm 0.21 \mathrm{bcd}$ & Robust shoots \\
\hline 11 & 0.6 & 0.04 & $268.81 \pm 2.76^{b c}$ & $5.30 \pm 0.08^{\mathrm{a}}$ & Robust shoots \\
\hline 12 & 0.6 & 0.06 & $251.68 \pm 8.26^{\text {def }}$ & $4.40 \pm 0.22 \mathrm{bcd}$ & Robust shoots \\
\hline 13 & 0.6 & 0.08 & $241.84 \pm 4.12^{\mathrm{fg}}$ & $4.10 \pm 0.29^{\mathrm{cd}}$ & Slightly crinkled leaf, callus \\
\hline 14 & 0.8 & 0.02 & $208.79 \pm 2.54^{\mathrm{ij}}$ & $3.67 \pm 0.09^{\mathrm{e}}$ & Crinkled leaf \\
\hline 15 & 0.8 & 0.04 & $224.23 \pm 3.70^{h}$ & $3.30 \pm 0.08^{f}$ & Crinkled leaf \\
\hline 16 & 0.8 & 0.06 & $204.14 \pm 2.12^{j}$ & $3.27 \pm 0.17^{\mathrm{f}}$ & Flavescence, partial callus \\
\hline 17 & 0.8 & 0.08 & $177.42 \pm 2.40^{\mathrm{k}}$ & $2.57 \pm 0.05 \mathrm{~g}$ & Flavescence, callus \\
\hline
\end{tabular}

Different superscript letters in the same column indicate significant differences at $p \leq 0.05$. $n=3$ indicates three replicates.

\subsection{Rooting and Acclimatization}

Without dark treatment, only a few shoots could regenerate roots and the rooting effects were not favorable (Table 4), with flavescent and withered leaves observed. In contrast, after $7 \mathrm{~d}$ of dark treatment, the status of the plants improved significantly. In addition, the rooting rate improved significantly $(p \leq 0.05)$ following the use of a combination of NAA and IBA, whereas medium supplemented with NAA alone presented considerably lower rooting rates. Following dark treatment, the maximum percentage of rooting $(87.78 \%)$ and the highest average root number of 4.89 were observed on ML medium supplemented with $0.6 \mathrm{mg} / \mathrm{L} \mathrm{NAA}$ and $1 \mathrm{mg} / \mathrm{L}$ IBA. The roots were healthy, and the leaves were verdant green and thriving (Figure 1f).

The survival rate of the plantlets transferred to plastic cups reached $89 \%$ after $90 \mathrm{~d}$, and their leaves were verdant green (Figure $1 \mathrm{~g}$ ). The lignified plants transferred to the field showed good growth. The regenerated plants were phenotypically identical to their mother plant, with ochre brown tender leaves and dark green mature leaves (Figure 1h,i).

\subsection{Genetic Fidelity Assessment}

In this study, 16 RAPD primers generated 70 distinct and scorable bands (Table 5), which ranged from 250 to $3000 \mathrm{bp}$, and the number of scorable bands generated with single RAPD primers varied from three to six. Six ISSR primers generated 31 distinct and scorable bands, which ranged from 500 to $3000 \mathrm{bp}$. The number of scorable bands generated with single ISSR primers ranged from four to five. No polymorphic bands were discovered between the regenerated plants and the mother plant, compared with those in the negative control (Figure 2; Figure 3). The results show the genetic consistency between the regenerated plants and the mother plant. 
Table 4. Effects of different combinations of NAA and IBA concentrations on rooting.

\begin{tabular}{|c|c|c|c|c|c|}
\hline Group & No. & NAA $(m g / L)$ & IBA $(\mathrm{mg} / \mathrm{L})$ & $\begin{array}{l}\text { Percentage of Rooting (\%) } \\
\quad(\text { Mean } \pm \text { SE, } n=3)\end{array}$ & $\begin{array}{l}\text { Average Root Number } \\
\quad(\text { Mean } \pm \mathrm{SE}, n=3)\end{array}$ \\
\hline \multirow{8}{*}{ Directly cultured by light } & 1 & 0.3 & 0 & $0^{\mathrm{j}}$ & $0^{\mathrm{i}}$ \\
\hline & 2 & 0.3 & 0.5 & $28.89 \pm 3.14^{\mathrm{gh}}$ & $1.34 \pm 0.07 \mathrm{gh}$ \\
\hline & 3 & 0.3 & 1 & $36.67 \pm 7.20 \mathrm{fg}$ & $1.53 \pm 0.07$ efg \\
\hline & 4 & 0.6 & 0 & $0^{j}$ & $0^{\mathrm{i}}$ \\
\hline & 5 & 0.6 & 0.5 & $41.11 \pm 6.85$ def & $1.81 \pm 0.20^{\mathrm{e}}$ \\
\hline & 6 & 0.6 & 1 & $52.22 \pm 5.67 \mathrm{~cd}$ & $2.59 \pm 0.14^{\mathrm{d}}$ \\
\hline & 7 & 0.9 & 0 & $13.33 \pm 2.72^{\mathrm{i}}$ & $1.15 \pm 0.11^{\mathrm{h}}$ \\
\hline & 8 & 0.9 & 0.5 & $27.78 \pm 4.16^{\mathrm{gh}}$ & $1.74 \pm 0.20$ ef \\
\hline \multirow{10}{*}{ Darkness for 7 days } & 9 & 0.9 & 1 & $20.00 \pm 2.72 \mathrm{hi}$ & $1.44 \pm 0.14^{\mathrm{fgh}}$ \\
\hline & 1 & 0.3 & 0 & $27.78 \pm 4.16^{\text {gh }}$ & $1.78 \pm 0.13^{e}$ \\
\hline & 2 & 0.3 & 0.5 & $51.11 \pm 6.85^{\mathrm{cd}}$ & $2.59 \pm 0.15^{d}$ \\
\hline & 3 & 0.3 & 1 & $60.00 \pm 7.20^{c}$ & $3.35 \pm 0.17^{c}$ \\
\hline & 4 & 0.6 & 0 & $37.78 \pm 4.16^{\text {efg }}$ & $2.34 \pm 0.11^{d}$ \\
\hline & 5 & 0.6 & 0.5 & $71.11 \pm 6.29^{b}$ & $4.26 \pm 0.27^{b}$ \\
\hline & 6 & 0.6 & 1 & $87.78 \pm 4.16^{\mathrm{a}}$ & $4.89 \pm 0.13^{\mathrm{a}}$ \\
\hline & 7 & 0.9 & 0 & $42.22 \pm 6.85^{\mathrm{def}}$ & $1.52 \pm 0.23^{\text {efg }}$ \\
\hline & 8 & 0.9 & 0.5 & $54.44 \pm 8.31^{c}$ & $3.40 \pm 0.30^{c}$ \\
\hline & 9 & 0.9 & 1 & $48.89 \pm 5.67^{\text {cde }}$ & $2.24 \pm 0.14^{\mathrm{d}}$ \\
\hline
\end{tabular}

Different superscript letters in the same column indicate significant differences at $p \leq 0.05$. $n=3$ indicates three replicates.

Table 5. Random amplified polymorphic DNA (RAPD) and inter simple sequence repeat (ISSR) primers, and the number and size of the amplified fragments.

\begin{tabular}{|c|c|c|c|}
\hline Primer Code & Sequence $\left(5^{\prime}-3^{\prime}\right)$ & No. of Scorable Bands & Range of Amplification (bp) \\
\hline \multicolumn{4}{|c|}{ RAPD } \\
\hline S10 & CTGCTGGGAC & 6 & $750-3000$ \\
\hline S11 & GTAGACCCGT & 5 & $1000-3000$ \\
\hline S17 & AGGGAACGAG & 3 & $500-3000$ \\
\hline S18 & CCACAGCAGT & 5 & $750-3000$ \\
\hline $\mathrm{S} 22$ & TGCCGAGCTG & 5 & $750-3000$ \\
\hline $\mathrm{S} 31$ & CAATCGCCGT & 4 & $250-2000$ \\
\hline S38 & CTGGGGCTGA & 5 & $750-3000$ \\
\hline $\mathrm{S} 40$ & GTTGCGATCC & 4 & $1000-3000$ \\
\hline S69 & CTCACCGTCC & 5 & $1000-3000$ \\
\hline S144 & GTGACATGCC & 5 & $750-3000$ \\
\hline S154 & TGCGGCTGAG & 4 & $750-2000$ \\
\hline S155 & ACGCACAACC & 4 & $1000-3000$ \\
\hline S160 & AACGGTGACC & 4 & $750-2000$ \\
\hline S163 & GGACTGCAGA & 5 & $2000-3000$ \\
\hline S173 & CTGGGGCTGA & 3 & $750-2000$ \\
\hline S174 & CTGGGGCTGA & 3 & $1000-2000$ \\
\hline Total & & 70 & \\
\hline \multicolumn{4}{|c|}{ ISSR } \\
\hline UBC811 & $(\mathrm{GA})_{8} \mathrm{G}$ & 5 & $500-3000$ \\
\hline UBC835 & $(\mathrm{SG})_{8} \mathrm{YC}$ & 4 & $750-3000$ \\
\hline UBC840 & $(\mathrm{GA})_{8} \mathrm{YT}$ & 5 & $500-3000$ \\
\hline UBC842 & $(G A)_{8} Y G$ & 6 & $750-3000$ \\
\hline UBC844 & $(\mathrm{CA})_{8} \mathrm{RG}$ & 5 & $1000-3000$ \\
\hline UBC864 & $(\mathrm{ATG})_{6}$ & 6 & $750-5000$ \\
\hline Total & & 31 & \\
\hline
\end{tabular}




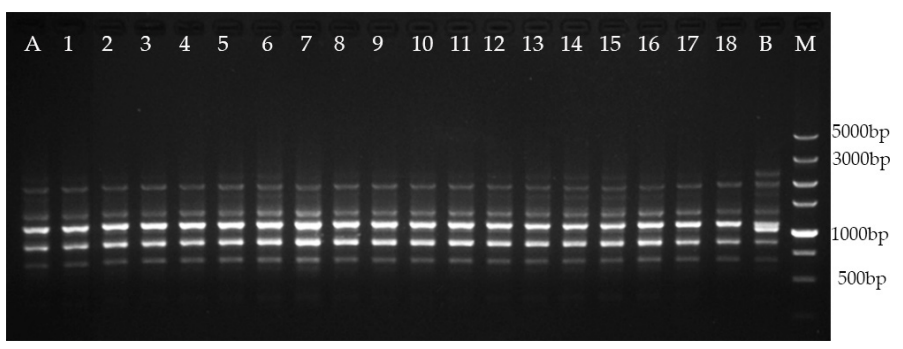

Figure 2. Amplification patterns generated with ISSR primer UBC811. Lane M: molecular marker (100-5000 bp); lane A: mother plant; lanes 1-18: regenerated plants from trunk shoot explant; lane B: negative control.

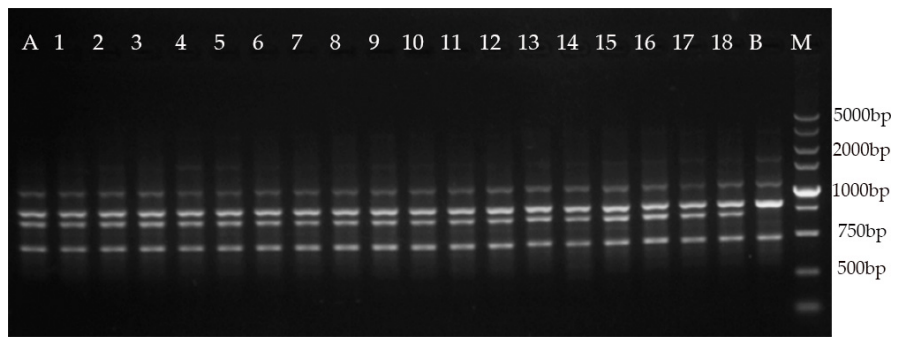

Figure 3. Amplification patterns generated with RAPD primer S31. Lane M: molecular marker (100-5000 bp); lane A: mother plant; lanes 1-18: regenerated plants from trunk shoot explant; lane B: negative control.

\section{Discussion}

The selection of appropriate explant types is essential for plant tissue culture [21]. In the preliminary experiment, we used the twigs of a mature tree and the withes at the base of the trunk as explants. However, we failed to establish an efficient sterile system using the method, as the explants were very thick, difficult to sterilize, and displayed severe browning. The trunk bud sprouts from a latent bud on the trunk, and latent buds on the trunk of M. lucida are relatively easy to germinate. In the present study, we used 3-5-cm-long trunk shoots as explants to overcome the above-mentioned challenges. This may be because the trunk buds are relatively thin and exposed to the environment for a short time, thereby increasing the disinfection efficiency.

To establish plant tissue culture, explant sterilization is necessary, which is especially difficult when dealing with endangered species, with limited explant availability [22,23]. Therefore, effective disinfection treatments, without damaging explant tissue, are important for the initiation in M. lucida [24]. This study indicated that a combination of 75\% ethanol (applied for $30 \mathrm{~s}$ ), $1 \%$ benzalkonium bromide (applied for $5 \mathrm{~min}$ ), and $0.1 \%$ mercuric chloride (applied for $5 \mathrm{~min}$ ) was the most suitable sterilization treatment of M. lucida explants. Prior to sterilization with mercuric chloride, $75 \%$ ethanol and $1 \%$ benzalkonium bromide could partially dissolve the epicuticular wax, and thus increase the effectiveness of subsequent disinfection [25]. A previous study indicated that mercuric chloride is more effective in combination with other chemical disinfectants than alone [26]. We also found that long-term sterilization $(7 \mathrm{~min}$ ) with mercuric chloride was toxic to explants, initially causing necrosis and then killing the explants, which is consistent with previous findings in Jatropha curcas [27].

The basal medium is important for micropropagation, and different plants require different nutritional components [28,29]. Among the four basal media tested in this study, ML medium better supported the regeneration and proliferation of shoots, which were poor on MS medium and WPM. This may be explained by the higher concentrations of $\mathrm{NO}_{3}{ }^{-}$and $\mathrm{NH}_{4}{ }^{+}$in MS medium than in ML medium, as excessive $\mathrm{NH}_{4}{ }^{+}$and $\mathrm{NO}_{3}{ }^{-}$have negative effects on organogenesis, such as hyperhydricity [30,31]. Meanwhile, the shoot performance was also poor on WPM and DCR media because of the low $\mathrm{NH}_{4}{ }^{+}$and $\mathrm{NO}_{3}{ }^{-}$concentrations hinders the growth of shoots [32]. Thus, it can be 
concluded that both high and low concentrations of these ions were not conducive for shoots growth and proliferation of M. lucida. In addition, explants grow better in ML medium and may benefit from moderate concentrations of $\mathrm{Ca}^{2+}$ because calcium is essential for the formation of the cell wall and facilitates cell elongation. When the $\mathrm{Ca}^{2+}$ concentrations are insufficient, cell wall synthesis is hindered, in turn adversely affecting cell division, causing stunted explant growth, and increasing hyperhydricity rate $[33,34]$.

The basal medium can only guarantee the survival of the culture and minimal physiological activities. The plant can initiate cell division, morphogenesis, organ differentiation, and development only when the medium is supplemented with appropriate plant growth regulators [35]. Auxins and cytokinins are generally considered the most important growth regulations in in vitro propagation [36]. A balance between auxins and cytokinins is necessary for the formation of buds and root [35]. It has been reported that an optimal combination of BA and NAA in a culture medium could significantly enhance shoot proliferation [37]. Thus, during organogenesis of Echinacea pallida from leaf explants, the most optimal combination was $6 \mathrm{mg} / \mathrm{L} \mathrm{BA}$ and $0.02 \mathrm{~mol} / \mathrm{L} \mathrm{NAA} \mathrm{[38],} \mathrm{whereas} \mathrm{Mamun} \mathrm{et} \mathrm{al.} \mathrm{[39]}$ achieved the maximum shoot multiplication rate of Albizia lebbeck on MS medium supplemented with $2.5 \mathrm{mg} / \mathrm{L} \mathrm{BA}$ and $0.2 \mathrm{mg} / \mathrm{L}$ NAA. However, in our study, ML medium supplemented with $0.4 \mathrm{mg} / \mathrm{L}$ BA and $0.04 \mathrm{mg} / \mathrm{L} \mathrm{NAA} \mathrm{was} \mathrm{the} \mathrm{most} \mathrm{suitable} \mathrm{combination} \mathrm{for} \mathrm{shoot} \mathrm{proliferation} \mathrm{and} \mathrm{elongation.}$ This result was different from that in other Magnoliaceae members, which showed the maximum multiplication rate under the combination of $0.2 \mathrm{mg} / \mathrm{L} \mathrm{BA}$ and $0.01 \mathrm{mg} / \mathrm{L} \mathrm{NAA} \mathrm{[11].} \mathrm{The} \mathrm{differences}$ may be due to the highly varying requisite concentration of each type of regulator, depending on the cultured plant and cultural conditions [40].

It has been reported that plants belonging to Magnoliaceae have poor root formation [41]. In this study, we found that dark treatment could effectively increase the rooting rate of M. lucida, because appropriate dark treatment can increase endogenous phenol levels and increase the utilization of carbohydrates, which in turn leads to a higher rooting percentage [42,43]. The result is consistent with those of studies performed on Parakmeria lotungensis and Sinomanglietia glauca [44]. A combination of $0.6 \mathrm{mg} / \mathrm{L} \mathrm{NAA}$ and $1 \mathrm{mg} / \mathrm{L}$ IBA and $7 \mathrm{~d}$ of initial dark treatment could effectively overcome the poor rooting by M. lucida. This result is different from that for Magnolia sirindhorniae, which can achieve a rooting rate of $95.67 \%$ only through the combination of appropriate concentrations of auxin [11]. The positive effects of a dark environment on different species need to be further explored.

Many factors can influence the stability of plants during tissue culture [45]. Therefore, it is important to evaluate the genetic stability of regenerated plants [46-48]. In the present study, RAPD and ISSR markers were used to analyze the genetic stability of regenerated plants after two years of subculture. No polymorphic bands were observed between the regenerated plants and the mother plant, when compared with those in the negative control, which confirmed the genetic uniformity of the regenerated plants. Our results suggest that the direct induction of multiple shoots could minimize the likelihood of instability, consistent with the results of previous studies [11].

The growth conditions play a significant role in optimizing and regulating the growth of in vitro plants. In these experiments, we directly placed the culture in a low-light and low-temperature environment to better control browning. Dark treatment was used to increase the rooting rate and good results were obtained, but further research on the influence of $\mathrm{pH}$, medium sugar content, and other conditions is needed.

\section{Materials and Methods}

\subsection{Plant Materials and Sterilization}

We used the excellent genotypes of M. lucida as the parent material and established a miniature cutting orchard by grafting to provide long-term sampling. The mother parent, with an excellent genotype, came from South China Agricultural University $\left(113^{\circ} 19^{\prime} \mathrm{E}, 23^{\circ} 04^{\prime} \mathrm{N}\right)$ (Figure 1). Trunk shoots were used as explants. Prior to the collection of explants, the mother plant was sprayed with 
carbendazim every $3 \mathrm{~d}$. When the trunk shoots were $3-5 \mathrm{~cm}$ long, they were cut and brought to the laboratory. After being thoroughly washed with a $5 \%(v / v)$ liquid detergent solution, the shoots were rinsed under running tap water for $2 \mathrm{~h}$. Subsequently, based on the research of Cui et al. [11] and Deng [44], we set up seven different sterilization schemes, with 100 explants each (Table 1). Thereafter, in the initial induction of explants, the sterilized explants were planted vertically on MS supplemented with $1 \mathrm{mg} / \mathrm{L} \mathrm{BA}$ and $0.05 \mathrm{mg} / \mathrm{L} \mathrm{NAA}$ (determined in a preliminary experiment). Following $20 \mathrm{~d}$ of culture, survival rates were recorded.

\subsection{Media and Culture Conditions}

MS, WPM, DCR, and ML media were used in this study. The ML basal medium was obtained by continuously improving the macronutrient in MS medium according to the growth status of the explants in preliminary experiments. The ML basal medium comprised the following macronutrient components (mg/L): $\mathrm{NH}_{4} \mathrm{NO}_{3}, 600 ; \mathrm{K}_{2} \mathrm{SO}_{4}, 660 ; \mathrm{KH}_{2} \mathrm{PO}_{4}, 200 ; \mathrm{MgSO}_{4} \cdot 7 \mathrm{H}_{2} \mathrm{O}, 370$; and $\mathrm{Ca}(\mathrm{NO} 3)_{2}, 556$. The other nutrients and vitamins were similar to those in the MS medium.

For shoot induction and proliferation, $30 \mathrm{~g} / \mathrm{L}$ sucrose was added to the medium and $15 \mathrm{~g} / \mathrm{L}$ sucrose to the rooting medium $[8,10]$. The $\mathrm{pH}$ of the media was adjusted to 5.8 ; then, the media was solidified with agar $(6 \mathrm{~g} / \mathrm{L})$ [11] and autoclaved at $121^{\circ} \mathrm{C}$ for $18 \mathrm{~min}$. To prevent browning, the inoculated culture was placed in a low light and low temperature environment $\left(24{ }^{\circ} \mathrm{C} \pm 2{ }^{\circ} \mathrm{C}\right.$, fluorescent light 12 -h/day photoperiod, $20 \mu \mathrm{mol} \mathrm{m} \mathrm{m}^{-2} \mathrm{~s}^{-1}$.

\subsection{Shoot Initiation}

Aseptic explants were cultured in four shoot induction media (Table 2). Each medium was supplemented with $1 \mathrm{mg} / \mathrm{L} \mathrm{BA}$, and $0.05 \mathrm{mg} / \mathrm{L} \mathrm{NAA}$ or IBA to achieve the maximum rate of shoot initiation. There were 12 treatments in total, and the treatments were repeated three times, with each repeat consisting of 30 explants. After $20 \mathrm{~d}$ of incubation, the induction rate and the growth state were recorded.

\subsection{Shoot Proliferation}

The ML medium was also selected as the basal medium to compare the combination effects of different BA and NAA concentrations on shoot proliferation (Table 3). BA was tested at concentrations of $0.2,0.4,0.6$, and $0.8 \mathrm{mg} / \mathrm{L}$, and NAA was tested at concentrations of $0.02,0.04,0.06$, and $0.08 \mathrm{mg} / \mathrm{L}$. The experiment was repeated three times, with each repeat consisting of 30 explants. After $20 \mathrm{~d}$ of incubation, the multiplication rate, number of shoots per explant, and growth state were recorded.

\subsection{Rooting}

Robust shoots ( $\geq 1.2 \mathrm{~cm}$ in height) were harvested and transferred to ML medium supplemented with different concentrations of NAA $(0.3,0.6,0.9 \mathrm{mg} / \mathrm{L})$ and IBA $(0,0.5,1 \mathrm{mg} / \mathrm{L})$ (Table 4). Each treatment was set in triplicate, with 30 explants and two groups. The first group was immediately cultured under light conditions and the second group was incubated for $7 \mathrm{~d}$ in dark (the tissue culture seedlings were placed in a dark environment) and then transferred to light conditions. After $30 \mathrm{~d}$ of culture, the rooting rate and average root number were recorded.

\subsection{Acclimatization}

After $30 \mathrm{~d}, 300$ plants with well-developed roots (root length $>1 \mathrm{~cm}$, robust) were transferred to a greenhouse for approximately 7-10 d. Thereafter, the plantlets were removed from the culture vessels and thoroughly washed under running tap water to remove adhering media. Subsequently, the plantlets were transplanted to plastic cups containing a mixture of peat soil, perlite, and coconut bran at a ratio of 3:1:1 (v/v/v); then, the seedlings were watered and covered with a shading net and provided timely ventilation. The percentage of survival was recorded after $90 \mathrm{~d}$. 


\subsection{Genetic Fidelity Assessment}

After two years of subculture of buds, the genetic stability was determined. Genomic DNA was extracted from young leaves of 18 regenerated plants and their mother plant using the cetyltrimethylammonium bromide method [49]. In addition, the genomic DNA of another M. lucida plant developed from a seed was extracted as the negative control. All plant DNA samples were analyzed using 16 RAPD and six ISSR primers (Table 5), which were selected for the genetic analysis of Magnoliaceae in previous studies [50,51]. The primers were provided by Tsingke Biological Technology (Beijing, China) and were used according to the previous studies and initial experiments. RAPD and ISSR DNA amplification was performed in $25 \mu \mathrm{L}$ of a reaction mixture containing $1.0 \mu \mathrm{L}$ of template DNA (20 ng/ $\mu \mathrm{L}), 12.5 \mu \mathrm{L}$ of $2 \times$ Taq Plus Master Mix (Beijing ComWin Biotech Co., Ltd., Beijing, China), $1.0 \mu \mathrm{L}$ of primer $(10 \mu \mathrm{M})$, and $10.5 \mu \mathrm{L}$ of $\mathrm{ddH}_{2} \mathrm{O}$. The ISSR amplification was performed under the following conditions: initial DNA denaturation at $94{ }^{\circ} \mathrm{C}$ for $5 \mathrm{~min}$, followed by 35 cycles of denaturation at $94{ }^{\circ} \mathrm{C}$ for $45 \mathrm{~s}$, annealing at $58^{\circ} \mathrm{C}$ for $1 \mathrm{~min}$, and extension at $72{ }^{\circ} \mathrm{C}$ for $2 \mathrm{~min}$, with a final extension at $72{ }^{\circ} \mathrm{C}$ for $10 \mathrm{~min}$. The RAPD amplification was performed under the following conditions: initial DNA denaturation at $94{ }^{\circ} \mathrm{C}$ for $5 \mathrm{~min}$, followed by 40 cycles of denaturation at $94{ }^{\circ} \mathrm{C}$ for $1 \mathrm{~min}$, annealing at $40{ }^{\circ} \mathrm{C}$ for $1 \mathrm{~min}$, and extension at $72{ }^{\circ} \mathrm{C}$ for $2 \mathrm{~min}$, with a final extension at $72{ }^{\circ} \mathrm{C}$ for $10 \mathrm{~min}$.

The ISSR and RAPD amplification products were subjected to electrophoresis on $1.5 \%$ agarose gels in $1.5 \%$ Tris-acetate-EDTA buffer using a 5000-bp DNA marker (Takara, Kyoto, Japan), and the gels were stained with $0.25 \mu \mathrm{g} / \mathrm{mL}$ ethidium bromide. A gel documentation system (Bio-Rad, Hercules, CA, USA) was used for visualization, and the analysis using the RAPD and ISSR primers was repeated three times.

\subsection{Statistical Analysis}

The following formulae were used to calculate different plant regeneration parameters:

- Induction rate $(\%)=$ number of induced explants/total number of explants $\times 100$

- Multiplication rate $(\%)=$ total number of shoots $\geq 0.3 \mathrm{~cm} /$ number of initial shoots on subcultured explants $\times 100$

- Number of shoots per explant $=$ total number of shoots $\geq 0.5 \mathrm{~cm} /$ number of explants

- $\quad$ Rooting rate $(\%)=$ number of rooted explants/number of explants $\times 100$

- Average root number $=$ total number of roots/number of rooted explants

IBM SPSS Statistics v23 (Armonk, NY, USA) was used for statistical analyses. Data were subjected to analysis of variance (ANOVA). Significant differences among means were calculated using Duncan's multiple range test at $p \leq 0.05$. The results are presented as mean \pm standard error of three replicates.

\section{Conclusions}

We established an efficient and reliable regeneration protocol for micropropagation of an endangered plant, from trunk shoot explants of an excellent genotype of M. lucida. The regenerated plants, which were propagated using this protocol, showed good growth and had verdant green and thriving leaves, as well as well-developed roots. The use of RAPD and ISSR genetic markers confirmed the genetic uniformity of the regenerated plants. These results indicated that the direct induction of multiple shoots could safely be used as an efficient tissue culture method for propagation of M. lucida. To the best of our knowledge, this is the first report of genetically sustainable M. lucida tissue culture from trunk shoot explants.

Author Contributions: Conceptualization, K.Z., X.D., and R.X.; methodology, data curation, and formal analysis, K.Z. and L.K.; writing_original draft preparation, review, and editing, L.K., Y.D., K.Z., Y.X., Y.Y., M.Z., X.D., and R.X. All authors have read and agreed to the published version of the manuscript.

Funding: This study was supported by the Forestry Public Welfare Industry Research of China, grant number 201404116, the National Natural Science Foundation of China, grant number 31670601, and the Forestry Science and Technology Innovation of Guangdong Province grant programs, grant numbers 2014KJCX006 and 2017 KJCX023. 
Acknowledgments: We are grateful to Ruchun Xi and Xiaomei Deng (supervisor of Lu Kang) for their support during this study.

Conflicts of Interest: The authors declare no conflicts of interest.

\section{References}

1. Vu, Q.; Xia, N. Manglietia lucida (Magnoliaceae), a newly recorded species for Vietnam. J. Trop. Subtrop. Bot. 2010, 18, 43-46.

2. Liu, Y. Magnolias of China; Beijing Sci. Technol. Press: Beijing, China, 2004.

3. Deng, Y.; Lin, J.; Wu, Q.; Liu, T.; Liu, M.; Deng, X. Review on Magnolia tissue culture technology. J. For. Environ. Sci. 2018, 34, 118-124.

4. Li, Z.; Guo, R. Review on propagation biology and analysis on endangered factors of endangered species of Manglietia. Life Sci. Res. 2014, 18, 90-94.

5. González, M.S.; Urrego, L.E. Habitat and conservation status of molinillo (Magnolia sambuensis) and laurel arenillo (Magnolia katiorum), two endangered species from the lowland, Colombia. Trop. Conserv. Sci. 2016, 9, 1-25. [CrossRef]

6. Rivers, M.; Beech, E.; Murphy, L.; Oldfield, S. The Red List of Magnoliaceae Revised and Extended; Botanic Gardens Conservation International: Surrey, UK, 2016.

7. Zeng, Z.; Deng, Y.; Liu, T.; Kang, L.; Guo, M.; Hong, W. Study on storage and germination characteristics of Magnolia lucida seeds. J. For. Environ. Sci. 2019, 35, 61-66.

8. Petrosyan, A.A. Variation in walnuts propagated by seed. Sadovodstvo 1970, 10, $26-27$.

9. Huai, H.; Ma, L.; Jia, Z. Research progress in tissue culture of Magnoliaceae. Pract. For. Technol. 2010, $8,27-29$.

10. Borah, R.; Kumaria, S.; Choudhury, H. In vitro plant regeneration of Magnolia punduana: An endemic and threatened plant species. Plant Tissue Cult. Biotechnol. 2017, 27, 153-159. [CrossRef]

11. Cui, Y.; Deng, Y.; Zheng, K.; Hu, X.; Zhu, M.; Deng, X.; Xi, R. An efficient micropropagation protocol for an endangered ornamental tree species (Magnolia sirindhorniae Noot. \& Chalermglin) and assessment of genetic uniformity through DNA markers. Sci. Rep. 2019, 9, 1-10.

12. Mata-Rosas, M.N.; Jiménez-Rodríguez, A.N.; Chávez-Avila, V.M. Somatic embryogenesis and organogenesis in Magnolia dealbata Zucc. (Magnoliaceae), an endangered, endemic Mexican species. HortScience 2006, 41, 1325-1329. [CrossRef]

13. Hussain, S.A.; Ahmad, N.; Anis, M. Synergetic effect of TDZ and BA on minimizing the post-exposure effects on axillary shoot proliferation and assessment of genetic fidelity in Rauvolfia tetraphylla (L.). Rend. Lincei. Sci. Fis. Nat. 2018, 29, 109-115. [CrossRef]

14. Bairu, M.W.; Aremu, A.O.; Van Staden, J. Somaclonal variation in plants: Causes and detection methods. Plant Growth Regul. 2011, 63, 147-173. [CrossRef]

15. Amiri, S.; Fotovat, R.; Tarinejhad, A.; Panahi, B.; Mohammadi, S.A. Optimization of hormonal combinations for in vitro regeneration of lesser periwinkle (Vinca minor L.) and assessment of genetic homogeneity. Proc. Natl. Acad. Sci. India Sect. B Biol. Sci. 2019, 1-7. [CrossRef]

16. Bennici, A.; Anzidei, M.; Vendramin, G.G. Genetic stability and uniformity of Foeniculum vulgare Mill. regenerated plants through organogenesis and somatic embryogenesis. Plant Sci. 2004, 166, 221-227. [CrossRef]

17. Smýkal, P.; Valledor, L.; Rodriguez, R.; Griga, M. Assessment of genetic and epigenetic stability in long-term in vitro shoot culture of pea (Pisum sativum L.). Plant Cell. Rep. 2007, 26, 1985-1998. [CrossRef]

18. Gupta, P.K.; Durzan, D.J. Shoot multiplication from mature trees of Douglas-fir (Pseudotsuga menziesii) and sugar pine (Pinus lambertiana). Plant Cell. Rep. 1985, 4, 177-179. [CrossRef]

19. Murashige, T.; Skoog, F. A revised medium for rapid growth and bio assays with tobacco tissue cultures. Physiol. Plant. 1962, 15, 473-497. [CrossRef]

20. Lloyd, G.; McCown, B. Commercially-feasible micropropagation of mountain laurel, Kalmia latifolia, by use of shoot-tip culture. Comb. Proc. Int. Plant Propag. Soc. 1980, 30, 421-427.

21. Tsay, H.S.; Lee, C.Y.; Agrawal, D.C.; Basker, S. Influence of ventilation closure, gelling agent and explant type on shoot bud proliferation and hyperhydricity in Scrophularia yoshimurae-A medicinal plant. In Vitro Cell. Dev. Biol. Plant 2006, 42, 445-449. [CrossRef] 
22. Cassells, A.C. Pathogen and microbial contamination management in micropropagation-An overview. In Pathogen and Microbial Contamination Management in Micropropagation; Cassells, A.C., Ed.; Springer: Dordrecht, The Netherlands, 1997; pp. 1-13.

23. Pinto, A.; Demattê, M.; Creste, S.; Barbosa, J. Seed and seedling surface-sterilization for in vitro culture of Tillandsia gardneri (Bromeliaceae). In Proceedings of the VII International Symposium on In Vitro Culture and Horticultural Breeding, Ghent, Belgium, 18 September 2011; Volume 961, pp. 383-389.

24. Murashige, T. Plant propagation through tissue cultures. Annu. Rev. Plant Physiol. 1974, 25, $135-166$. [CrossRef]

25. Enjalric, F.; Carron, M.-P.; Lardet, L. Contamination of primary cultures in tropical areas: The case of Hevea brasiliensis. Bact. Bact.-like Contam. Plant Tissue Cult. 1988, 225, 57-66. [CrossRef]

26. Rakesh, K.; Bangarwa, K.; Yadava, R. Study on effect of different sterilization treatments on culture establishment in Eucalyptus tereticornis. J. Trop. For. 2012, 28, 72-75.

27. Garg, R.K.; Srivastava, V.; Kaur, K.; Gosal, S. Effect of sterilization treatments on culture establishment in Jatropha curcas L. Karnataka J. Agric. Sci. 2014, 27, 190-192.

28. Phillips, G.C.; Garda, M. Plant tissue culture media and practices: An overview. In Vitro Cell. Dev. Biol. Plant 2019, 55, 242-257. [CrossRef]

29. Schenk, R.U.; Hildebrandt, A. Medium and techniques for induction and growth of monocotyledonous and dicotyledonous plant cell cultures. Can. J. Bot. 1972, 50, 199-204. [CrossRef]

30. De Diego, N.; Montalbán, I.; Fernández de Larrinoa, E.; Moncaleán, P. In vitro regeneration of Pinus pinaster adult trees. Can. J. For. Res. 2008, 38, 2607-2615. [CrossRef]

31. Tuskan, G.; Sargent, W.; Rensema, T.; Walla, J. Influence of plant growth regulators, basal media and carbohydrate levels on the in vitro development of Pinus ponderosa (Dougl. ex Law.) cotyledon explants. Plant Cell Tissue Organ. Cult. 1990, 20, 47-52. [CrossRef]

32. Ivanova, M.; Staden, J.V. Nitrogen source, concentration, and $\mathrm{NH}_{4}{ }^{+}: \mathrm{NO}_{3}$ ratio influence shoot regeneration and hyperhydricity in tissue cultured Aloe polyphylla. Plant Cell Tissue Organ. Cult. 2009, 99, 167-174. [CrossRef]

33. Feng, F.; Li, H.; Xie, J. The occurrence and prevention of vitrification of test-tube seedlings in aloe tissue culture. J. Southwest Univ. (Nat. Sci. Ed.) 2001, 23, 449-451.

34. Bairu, M.W.; Stirk, W.A.; Staden, J.V. Factors contributing to In Vitro shoot-tip necrosis and their physiological interactions. Plant Cell Tissue Organ. Cult. 2009, 98, 239-248. [CrossRef]

35. Gaspar, T.; Kevers, C.; Penel, C.; Greppin, H.; Reid, D.M.; Thorpe, T.A. Plant hormones and plant growth regulators in plant tissue culture. In Vitro Cell. Dev. Biol. Plant 1996, 32, 272-289. [CrossRef]

36. George, E.F.; Hall, M.A.; De Klerk, G.-J. Plant growth regulators II: Cytokinins, their analogues and antagonists. In Plant Propagation by Tissue Culture; George, E.F., Hall, M.A., De Klerk, G.-J., Eds.; Springer: Basel, Switzerland, 2008; Volume 1, pp. 205-226.

37. Perveen, S.; Varshney, A.; Anis, M.; Aref, I.M. Influence of cytokinins, basal media and pH on adventitious shoot regeneration from excised root cultures of Albizia lebbeck. J. For. Res. 2011, 22, 47-52. [CrossRef]

38. Koroch, A.; Kapteyn, J.; Juliani, H.; Simon, J. In vitro regeneration of Echinacea pallida from leaf explants. In Vitro Cell. Dev. Biol. Plant 2003, 39, 415-418. [CrossRef]

39. Mamun, A.; Matin, M.; Bari, M.; Siddique, N.; Sultana, R.; Rahman, M.; Musa, A. Micropropagation of woody legume (Albizia lebbeck) through tissue culture. Pak. J. Biol. Sci. 2004, 7, 1099-1103.

40. Greenway, M.B.; Phillips, I.C.; Lloyd, M.N.; Hubstenberger, J.F.; Phillips, G.C. A nutrient medium for diverse applications and tissue growth of plant species in vitro. In Vitro Cell. Dev. Biol. Plant 2012, 48, 403-410. [CrossRef]

41. Gao, Z.; Gao, X.; Tang, J.; Xin, P.; Zhao, X.L.W.; Yu, F. Research progress on tissue culture of Magnoliaceae in China. Jiangxi Sci. 2013, 31, 53-57.

42. Druart, P.; Kevers, C.; Boxus, P.; Gaspar, T. In vitro promotion of root formation by apple shoots through darkness effect on endogenous phenols and peroxidases. Z. Pflanzenphysiol. 1982, 108, 429-436. [CrossRef]

43. Pan, M.; Van Staden, J. The effect of activated charcoal and auxins on root formation by hypocotyl segments of Daucus carota. S. Afr. J. Bot. 2002, 68, 349-356. [CrossRef]

44. Deng, X. A Study on Tissue Culture and Rapid Propagation of Parakmeria Lotungensis (Chun et C. Tsoong) Law, Sinomanglietia Glauca Z.X. Yu et Q.Y. Zhang and Photinia $\times$ Fraseri 'Red Robin'. Ph.D. Thesis, Nanjing Forestry University, Nanjing, China, 2004. 
45. Domínguez, F.; Chávez, M.; Garduño-Ramírez, M.L.; Chávez-Avila, V.M.; Mata, M.; Cruz-Sosa, F. Honokiol and magnolol production by in vitro micropropagated plants of Magnolia dealbata, an endangered endemic Mexican species. Nat. Prod. Commun. 2010, 5, 1934578X1000500213. [CrossRef]

46. Giri, C.; Shyamkumar, B.; Anjaneyulu, C. Progress in tissue culture, genetic transformation and applications of biotechnology to trees: An overview. Trees 2004, 18, 115-135. [CrossRef]

47. Kumar, S.; Mangal, M.; Dhawan, A.; Singh, N. Assessment of genetic fidelity of micropropagated plants of Simmondsia chinensis (Link) Schneider using RAPD and ISSR markers. Acta Physiol. Plant. 2011, 33, 2541-2545. [CrossRef]

48. Chavan, J.; Gaikwad, N.; Kshirsagar, P.; Umdale, S.; Bhat, K.; Dixit, G.; Yadav, S. Highly efficient In Vitro proliferation and genetic stability analysis of micropropagated Ceropegia evansii by RAPD and ISSR markers: A critically endangered plant of Western Ghats. Plant Biosyst. 2015, 149, 442-450. [CrossRef]

49. Porebski, S.; Bailey, L.G.; Baum, B.R. Modification of a CTAB DNA extraction protocol for plants containing high polysaccharide and polyphenol components. Plant Mol. Biol. Report. 1997, 15, 8-15. [CrossRef]

50. Yu, H.-H.; Yang, Z.-L.; Sun, B.; Liu, R.-N. Genetic diversity and relationship of endangered plant Magnolia officinalis (Magnoliaceae) assessed with ISSR polymorphisms. Biochem. Syst. Ecol. 2011, 39, 71-78. [CrossRef]

51. Zhou, H.; Shao, M.; Wu, H.; Yin, J.; Ji, K. Genetic diversity among 10 genera 17 species of Magnoliaceae by RAPD marker. Biotechnology 2011, 6, 46-49.

(C) 2020 by the authors. Licensee MDPI, Basel, Switzerland. This article is an open access article distributed under the terms and conditions of the Creative Commons Attribution (CC BY) license (http://creativecommons.org/licenses/by/4.0/). 